\title{
Comparative Study of Heat Absorbing Packed Bed Regenerator for Space Heating Using Clay And Waste Hard Rubber for Long Term Heat Storage
}

\author{
Shivasheesh Kaushik ${ }^{1}$, Dr. Anirudh Gupta ${ }^{2}$ \\ ${ }^{1}$ Assistant Professor, Mechanical Engineering Department, Amrapali Institute of Technology, Haldwani \\ ${ }^{2}$ Associate Professor, Mechanical BTKIT Dwarahat, Uttarakhand, India
}

\begin{abstract}
Solar radiation is available for limited hours only in a single day. As a result it is often necessary to use a storage system to store this limited hour's available solar radiation, so that it can be used for various applications. Space heating is one of the most important demands of people in winters. Therefore there is a need of a storage system which provides heating in off shine hours during winter. Present work deals with the experimental study of various vital thermal energy storage system parameters such as packed bed size, heat absorbing material particle diameter and number of beds. Besides this, mass velocity of air in charging and discharging of heat absorbing packed bed, pressure drop across bed, cycle time of charging and discharging the packed bed are also studied through experimental setup and validation is carried out through theoretically numerical based equations. Based on the optimization, material bed length $1.5 \mathrm{~m}$, diameter of material bed $0.1 \mathrm{~m}$, material particle diameter $0.03 \mathrm{~m}$, number of beds 2 and mass velocity of working fluid in charging and discharging $0.0125 \mathrm{~kg} / \mathrm{m}^{2}-\mathrm{s}, 0.00796 \mathrm{~kg} / \mathrm{m}^{2}-\mathrm{s}$ respectively, has been proposed.
\end{abstract}

Keywords: Concentrated solar power, Thermal storage, Packed Bed, Porous media, Sensible heat

\section{Nomenclatures}

\begin{tabular}{|c|c|c|}
\hline Symbol & Description & Unit \\
\hline $\mathrm{A}_{\sigma}$ & Cross sectional area of heat absorbing bed & $\mathrm{m}^{2}$ \\
\hline$A_{h}$ & Heat transfer area & $\mathrm{m}^{2}$ \\
\hline $\mathrm{C}_{\mathrm{pg}}$ & Specific heat of air & $\mathrm{J} / \mathrm{kg}-\mathrm{K}$ \\
\hline $\mathrm{C}_{\mathrm{ps}}$ & Specific heat of solid & $\mathrm{J} / \mathrm{kg}-\mathrm{K}$ \\
\hline $\mathrm{D}_{\mathrm{b}}$ & Diameter of heat absorbing bed & $\mathrm{m}$ \\
\hline$d_{p}$ & Particle diameter & $\mathrm{m}$ \\
\hline $\mathrm{G}$ & Mass velocity & $\mathrm{kg} / \mathrm{m}^{2}-\mathrm{s}$ \\
\hline $\mathrm{M}$ & Mass flow rate & $\mathrm{kg} / \mathrm{s}$ \\
\hline $\mathrm{H}_{\mathrm{c}}$ & Average heat transfer coefficient & $\mathrm{W} / \mathrm{m}^{\circ} \mathrm{C}$ \\
\hline $\mathrm{k}_{\text {,eff }}$ & Effective thermal conductivity of air & $\mathrm{W} / \mathrm{m}^{\circ} \mathrm{C}$ \\
\hline $\mathrm{L}_{b}$ & Length of bed & $\mathrm{m}$ \\
\hline $\mathrm{P}$ & Pressure drop across rock bed & $\mathrm{Pa}$ \\
\hline $\mathrm{t}_{\mathrm{av}}$ & Average temperature & ${ }^{\circ} \mathrm{C}$ \\
\hline$\Delta \mathrm{T}$ & Mean air temperature & ${ }^{\circ} \mathrm{C}$ \\
\hline $\mathrm{T}_{\mathrm{amb}}$ & Air initial temperature & ${ }^{\circ} \mathrm{C}$ \\
\hline$t_{5}$ & Supply air temperature & ${ }^{\circ} \mathrm{C}$ \\
\hline $\mathrm{V}_{\mathrm{b}}$ & Velocity of air in rock bed & $\mathrm{m} / \mathrm{s}$ \\
\hline $\mathrm{V}_{0}$ & Velocity of air at onifice & $\mathrm{m} / \mathrm{s}$ \\
\hline$A_{b}$ & Area of air in heat absorbing bed & $\mathrm{m}$ \\
\hline $\mathrm{A}_{0}$ & Area of air at orifice & $\mathrm{m}$ \\
\hline$Q_{u}$ & Heat flux & $\mathrm{W} / \mathrm{m}^{2}$ \\
\hline$\mu$ & Dynamic viscosity of air & $\mathrm{kg} / \mathrm{m}-\mathrm{s}$ \\
\hline $\mathrm{D}$ & Effective particle diameter & $\mathrm{m}$ \\
\hline $\operatorname{Rz}$ & Density of air & $\mathrm{kg} / \mathrm{m}^{3}$ \\
\hline Ra. & Density of solid & $\mathrm{kg} / \mathrm{m}^{3}$ \\
\hline
\end{tabular}

\section{Introduction}

As the demand for energy increases in the commercial industry, as well as the household applications, the demand for more efficient energy system and less expensive processes is increasing along with it. The continuous increase in the level of greenhouse gas emissions and hike in the fuel prices are the main reasons behind efforts to more effectively utilize various sources of renewable energy. A study on energy efficiency in buildings (EEB) shows that the global building sector needs to cut energy consumption in buildings 60 percent by 2050 to help meet global climate change targets. According to the World Business Council for Sustainable Development (WBCSD), buildings account for 40 percent of the world's energy use with the resulting carbon emissions. The sun is the powerful source of energy, it provides much more energy in some hour than used by the people in one year, but then limitations of the source turn up. The amount of sunlight that arrives at the earth surface is not constant. Thermal energy storage is efficient to domestic hot water and space heating demands but still need auxiliary energy to cover the demands.Space heating is one of the most important fields that offer simple, direct utilization of solar energy since only a relative small increase in temperature is needed. The main aim of this comparison study between waste hard rubber and clay is to find the best suitable material for long term heat storage.

1) To determine the optimum mass flow rate for hot air which is maintained at three different temperature i.e. $40^{\circ}$ $\mathrm{C}, 45^{\circ} \mathrm{C}$ and $50^{\circ} \mathrm{C}$.

2) To determine the Optimum supply air temperature and mass flow rate throughout the night for comfort inside the room.

3) Optimization of heating bed parameters such as:

- Length of the Bed.

- Diameter of the Bed.

- Porosity.

- Rubber Particle Diameter.

- Number of Beds.

- Charging and Discharging Characteristics of Bed. 


\section{International Journal of Science and Research (IJSR) \\ ISSN (Online): 2319-7064}

Index Copernicus Value (2013): 6.14 | Impact Factor (2014): 5.611

\section{Experimental Details}

Packed beds generally represent the most suitable storage units for air-based solar heating systems. Storage in Packed bed is accomplished by heating the heat absorbing material with hot air with the help of solar air heater when solar insolation is available (day) and then utilizing it as a source of heating when solar insolation is absent (night). Packed bed acts as a regenerator in charging and discharging processes. A schematic diagram of packed bed sensible heat storage technique is as shown in Fig.1.1. The cylindrical heater is made up of $1 \mathrm{~m}$ long Iron pipe and nichrome wire and screws. The cylindrical hollow heater have $10.6 \mathrm{~cm}$ outer diameter with heavy insulation and $7.6 \mathrm{~cm}$ inner diameter of iron pipe which hold heavy insulation above the surface of the iron pipe about $3 \mathrm{~cm}$ in thickness which is insulated by using coconut rope and Paris of plaster material . Nichrome wires are mounted circularly on the cylindrical rod made of Paris of plaster as shown in above figure. The cylindrical heater gave heat to the packed bed with help of blower.Cylindrical heater is placed $2.7 \mathrm{~m}$ away the packed bed to supply heat to the absorbing material placed in the packed bed.

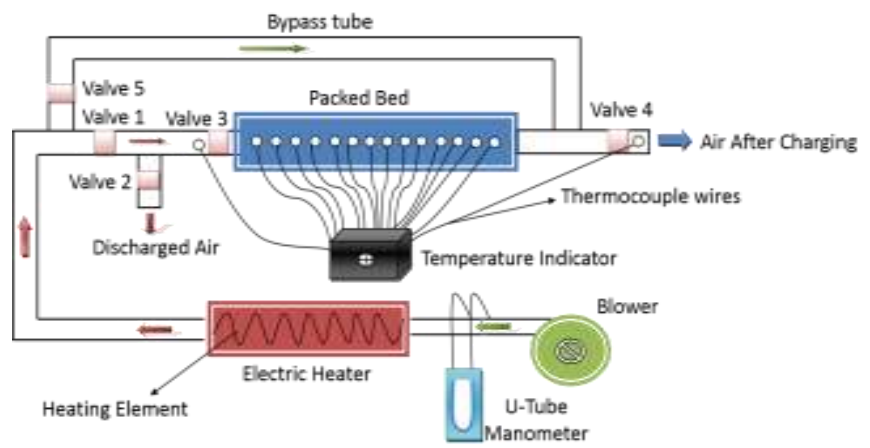

Figure 1.1: Schematic Diagram of Experimental Setup



Figure 1.2: Photographic view of Inner heating coil of heater mounted circular on P.O.P insulating material rod

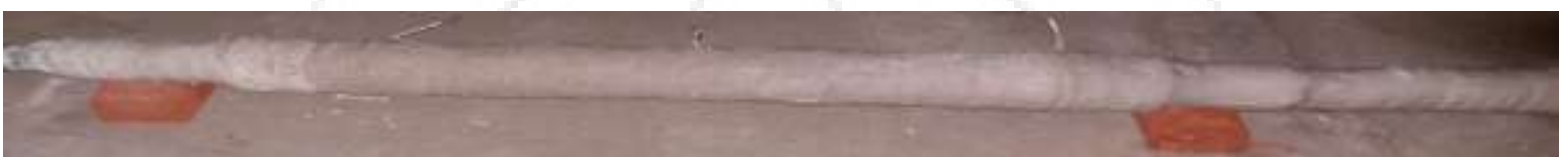

Figure 1.3: Photographic view of Outer section of heater insulated with P.O.P and Coconut Rope

\section{Design of Circular Duct/Packed (Heat Absorbing) Bed}

Length of the packed bed $\mathrm{L}_{\mathrm{b}}=1.5 \mathrm{~m}$

Diameter of the packed bed $\mathrm{D}_{\mathrm{b}}=0.10 \mathrm{~m}$
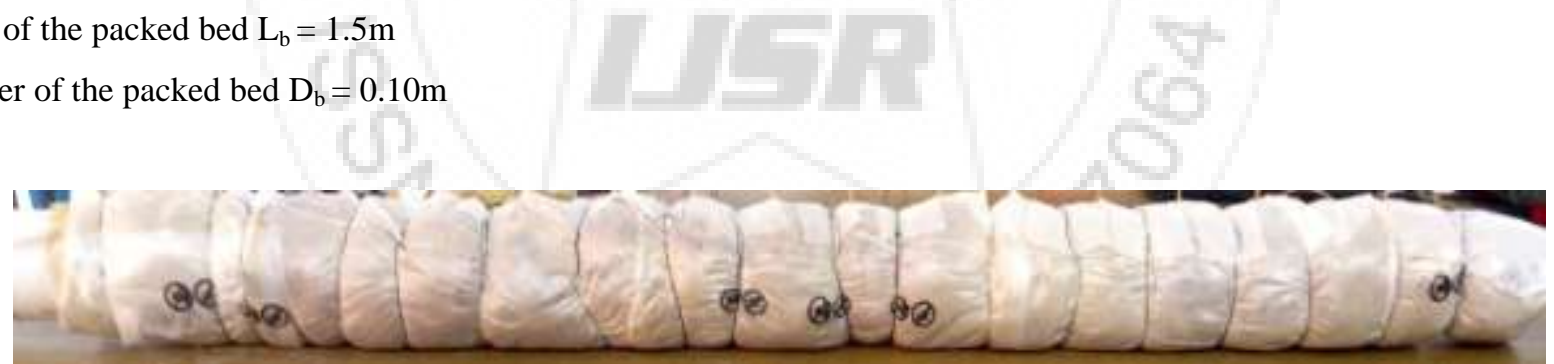

Figure 1.4: Photographic view of packed bed with insulation

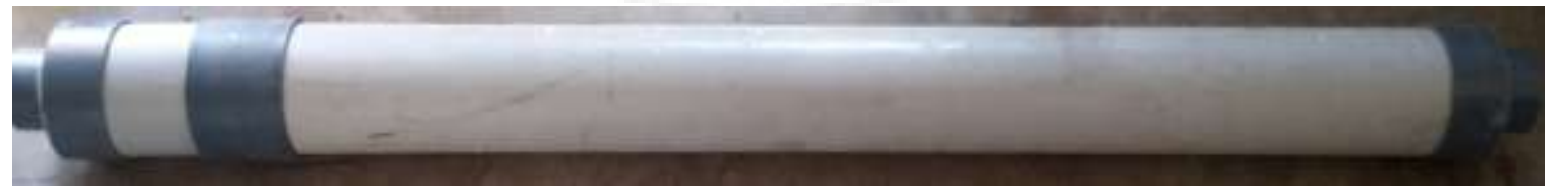

Figure 1.5: Photographic view of packed bed without insulation



Figure 1.6: Photographic view of preparing for packing/rapping the Glass Wool (insulation) over the $1.6 \mathrm{~m}$ long pipe for proper insulation

After assembling the whole experimental setup, the measuring instruments were installed in proper position and electric connections of the following namely variac; temperature indicator and cylindrical heater were made. Air is sucked through the blower, driven by motor to the duct/packed (heat absorbing) bed. Before heating the duct/packed (heat absorbing) bed all thermocouples were checked by adjusting the corresponding selector switch

\section{Volume 5 Issue 2, February 2016 www.ijsr.net}




\section{International Journal of Science and Research (IJSR) \\ ISSN (Online): 2319-7064}

Index Copernicus Value (2013): 6.14 | Impact Factor (2014): 5.611

position. Before starting the experiment all the joints are sealed with the help rapid fast araldite and m-seal, so that no leakage occurs from the duct/ packed (heat absorbing) bed. After that Variac should be adjusted to the proper voltage and this voltage is supplied to the strip heater. The steady state condition occurs after 1.5-2 hours after starting the heater and blower. When steady state condition occur the temperature of different thermocouples should be noted. Then the mass flow rate can be changed with the help of gate valve attached to the blower and thus by changing the different decided temperature and mass flow rate the process should be repeated until all the readings are achieved for the

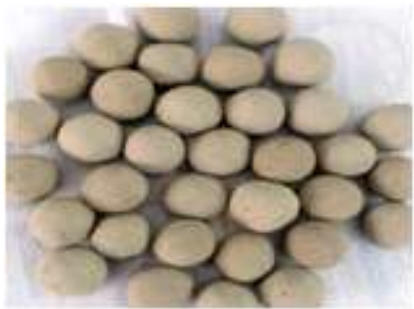

(a) Fig Clay Balls

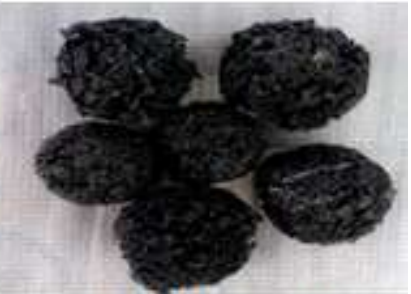

(b) Rubber balls

Figure 1.7: Photographic view of Absorbing materials material placed in the packed (heat absorbing) bed.

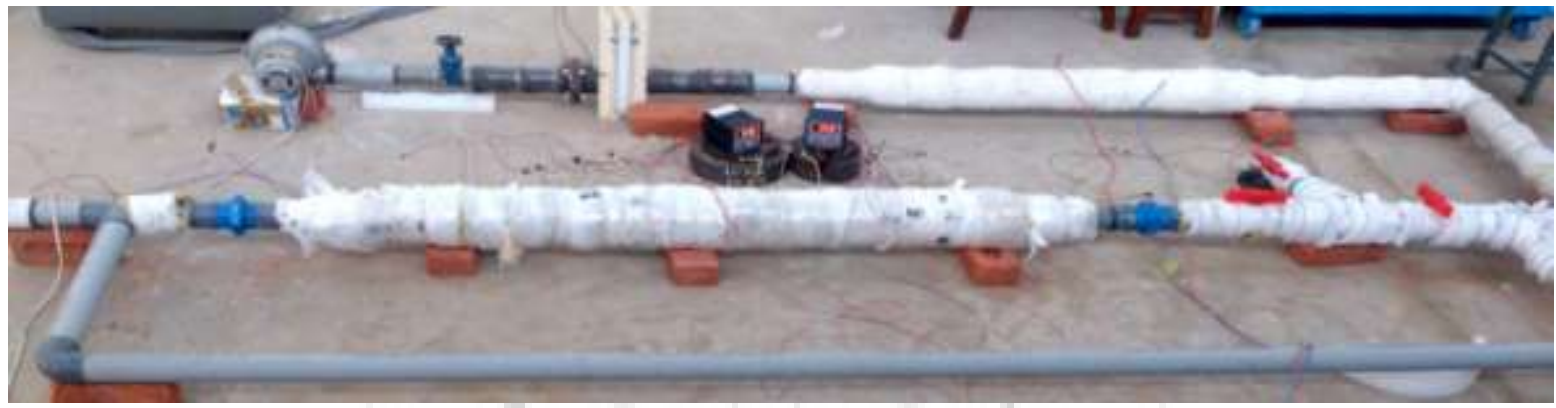

Figure 1.8: Photographic view of experimental setup (duct side)

\section{Results and Discussion}

The execution of packed bed heat storage system relies on different parameters. The impact of three distinctive air channel temperatures i.e. $40^{\circ} \mathrm{C}, 45^{\circ} \mathrm{C}$ and $50^{\circ} \mathrm{C}$ and the three mass flow rates of air i.e. $0.00796 \mathrm{~kg} / \mathrm{s}, 0.00985 \mathrm{~kg} / \mathrm{s}$, and $0.0125 \mathrm{~kg} / \mathrm{s}$ on charging and releasing profile of packed bed were studied. The measurements of the bed were $1.5 \mathrm{~m}$ in length and $0.1 \mathrm{~m}$ diameter with uniform porosity of 0.39 and material of $0.04 \mathrm{~m}$ in diameter.This part incorporates the approval of present work with Transient investigation utilizing numerical method, charging and discharging profile of plastic material inside the bed for three distinctive mass stream rates of air with diverse air inlet temperatures.

\subsection{Results for Air Inlet Temperature of $40^{\circ} \mathrm{c}$ During} Charging for Waste Hard Rubber Material

At first air inlet temperature was situated to be $40^{\circ} \mathrm{C}$ utilizing electric heater and blower and the mass flow rate was set to be $0.00985 \mathrm{~kg} / \mathrm{s}$ utilizing electric Variac. Presently the warmed air was gone through the packed bed. As the warmed air goes through the packed bed, the temperature of the packed bed will increment because of heat exchange from high temperature air to shakes. The temperature profile inside the packed bed at the time interim of 10 minutes was plotted in graph. The temperature from inside the packed bed diminishes with length of bed and this profile moved upwards with the compass of time. It is seen from the graph that packed bed achieve an estimated uniform temperature of $40^{\circ} \mathrm{C}$ after 80 minutes. The charging time of bed with inlet air temperature of $40^{\circ} \mathrm{C}$ and mass flow rate of air as 0.00796 $\mathrm{kg} / \mathrm{s}$ decreases to about 20 minutes, as compared to mass flow rate of $0.00985 \mathrm{~kg} / \mathrm{s}$ and same inlet temperature. It also decreases to 15 minutes when mass flow rate is $0.0125 \mathrm{~kg} / \mathrm{s}$. The optimum result for charging bed inlet air temperature at $40^{\circ} \mathrm{Cwhen}$ mass flow rate is $0.0125 \mathrm{~kg} / \mathrm{s}$ is 45 minutes as shown in Fig 2.3.

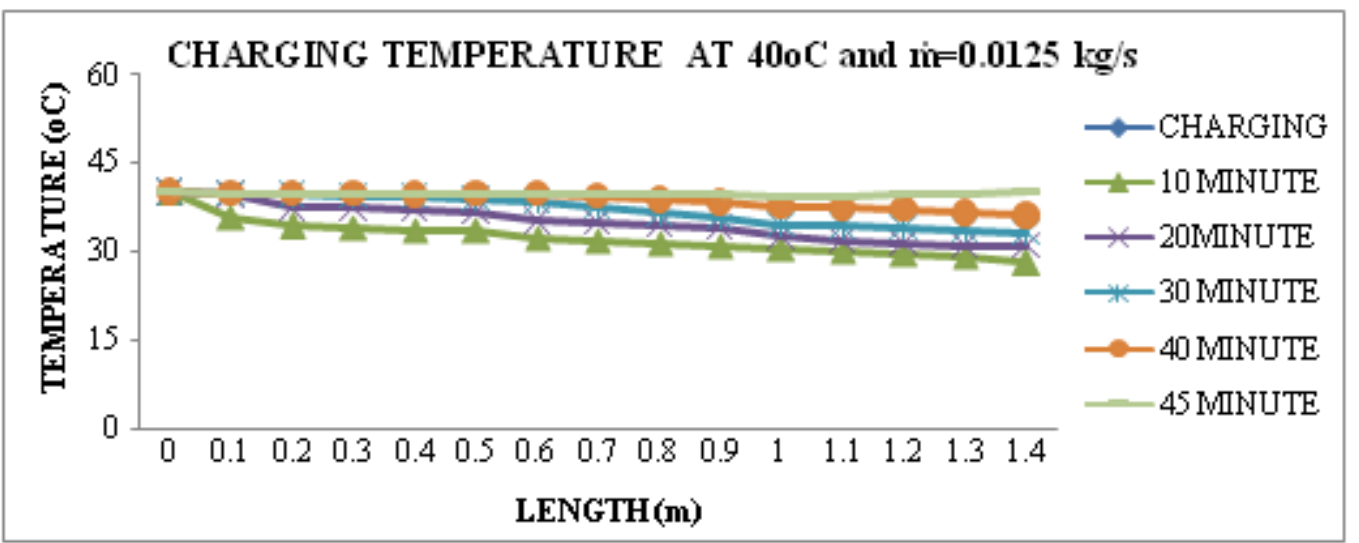

Figure 2.1: Temperature profile of charging packed bed with $\dot{\mathrm{m}}=0.0677 \mathrm{~kg} / \mathrm{s}$ and inlet air temperature at $40^{\circ} \mathrm{C}$. 


\section{International Journal of Science and Research (IJSR) \\ ISSN (Online): 2319-7064}

Index Copernicus Value (2013): 6.14 | Impact Factor (2014): 5.611

\subsection{Results for Air Inlet Temperature of $40^{\circ} \mathrm{c}$ During Discharging}

In the wake of discharging cycle, the climatic air is gone through the heated packed bed, during which the heat exchange happens from warmed bed to air and the temperature of air will increment with the lessening in temperature of material utilized inside the bed i.e. Waste Hard Rubber. The ambient air temperature coming directly from the blower during the discharging cycle was around $31.6^{\circ} \mathrm{C}$, so, when the temperature of the bed goes down the ambient temperature of the air during the discharging cycle, the bed was assumed to be discharged completely. The temperature profile of waste hard rubber material inside the packed bed for mass flow rate of $0.00796 \mathrm{~kg} / \mathrm{s}$, in the wake of charging time of same mass flow rate with $40^{\circ} \mathrm{C}$ air inlet temperature is plotted in Fig.1.8. It is seen from the figure that the packed bed releases totally following 120 minutes. The discharging time for the mass flow rate of $0.00985 \mathrm{~kg} / \mathrm{s}$ and inlet air temperature $40{ }^{\circ} \mathrm{C}$ decreases to 20 minutes when compared with the mass rate of $0.00796 \mathrm{~kg} / \mathrm{s}$ Fig. 2.1 shows that the discharging time further decreases to 40 minutes when mass flow rate was $0.0125 \mathrm{~kg} / \mathrm{s}$ for the same inlet charging temperature of $40^{\circ} \mathrm{C}$. The discharging time reduces to 60 minutes and 20 minutes for the mass flow rate of $0.0125 \mathrm{~kg} / \mathrm{s}$ when compared to the discharging time for the mass flow rates of $0.00796 \mathrm{~kg} / \mathrm{s}$ and $0.00985 \mathrm{~kg} / \mathrm{s}$ respectively for same inlet bed charging temperature of $40^{\circ} \mathrm{C}$. The optimum result for discharging bed for maintained temperature at $40^{\circ} \mathrm{C}$ when mass flow rate is $0.00796 \mathrm{~kg} / \mathrm{sis} 120$ minutes as shown in Fig 2.2.

This impact is plainly seen from the results, in which the mass flow rates were taken as $0.00985 \mathrm{~kg} / \mathrm{s}$ and $0.0125 \mathrm{~kg} / \mathrm{s}$ separately. The charging time from the figure watched were 65 minutes and 50 minutes for two diverse mass flow rates as specified previously. The optimum result for charging bed inlet air temperature at $45^{\circ} \mathrm{Cwhen}$ mass flow rate is 0.0125 $\mathrm{kg} / \mathrm{s}$ is 50 minutes as shown in Fig 2.2.

\subsection{Results for Air Inlet Temperature of $40^{\circ} \mathrm{C}$ During Charging for Clay Material}

Here, the air inlet temperature is situated to be $50^{\circ} \mathrm{C}$ and the charging profile of material inside the bed is to be concentrated on for mass flow rate of $0.00796 \mathrm{~kg} / \mathrm{s}$ of air.Results demonstrate the temperature profile of bed during the charging for mass stream of $0.00796 \mathrm{~kg} / \mathrm{s}$ and $50^{\circ} \mathrm{C}$ inlet air temperature. It is observed from the figure that the charging time after the bed gets completely charged is nearly 90 minutes. It is also observed from the result that the maximum temperature reached to about $50^{\circ} \mathrm{C}$ very slowly as compared to inlet temperature of $40^{\circ} \mathrm{C}$ and after that it reaches to uniform temperature of $50^{\circ} \mathrm{C}$. As the mass stream rate of air expands, the charging time of the bed diminishes. This impact is plainly seen from the result, in which the mass flow rates were taken as $0.00985 \mathrm{~kg} / \mathrm{s}$ and $0.0125 \mathrm{~kg} / \mathrm{s}$ separately.

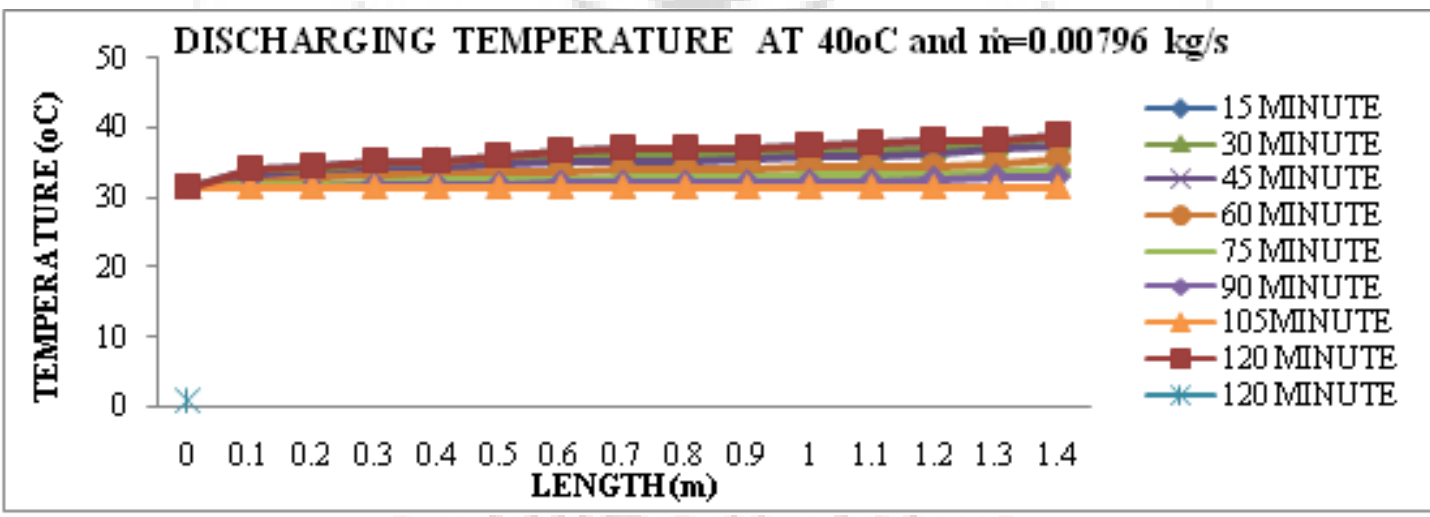

Figure 2.2: Temperature profile of discharging bed with $\dot{\mathrm{m}}=0.00796 \mathrm{~kg} / \mathrm{s}$ and ambient temperature of air as $27.5^{\circ} \mathrm{C}$

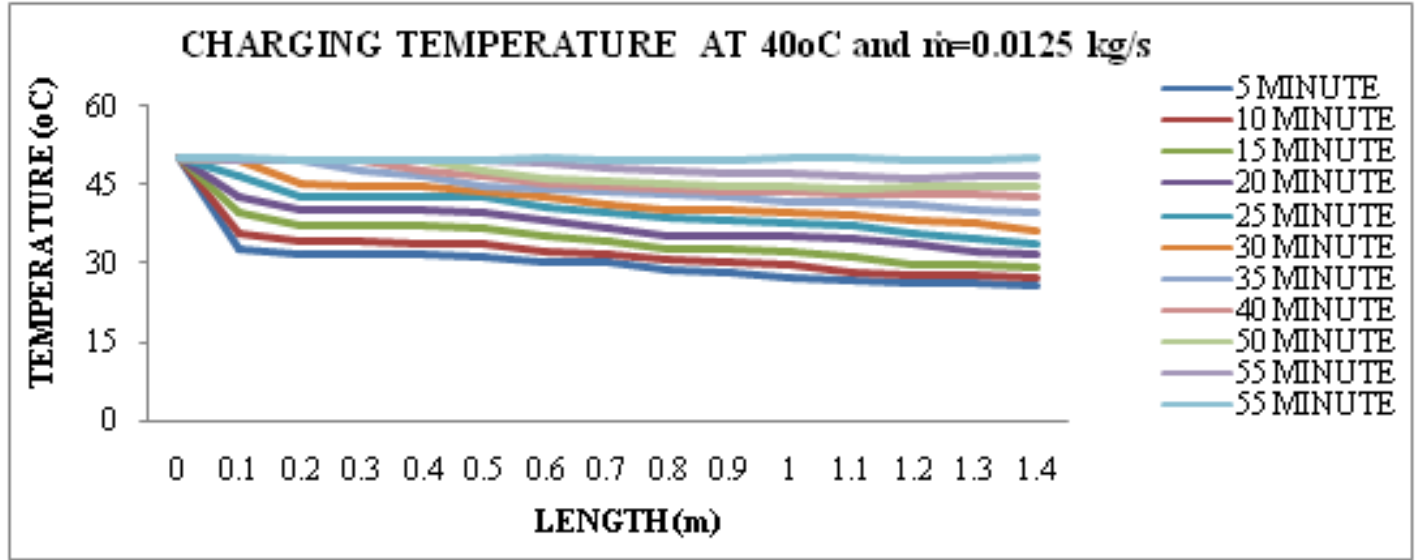

Figure 2.3: Temperature profile of charging packed bed with $\dot{\mathrm{m}}=0.0125 \mathrm{~kg} / \mathrm{s}$ and inlet air temperature at $50^{\circ} \mathrm{C}$.

The charging time from the figure watched were 70 minutes and 55 minutes for two diverse mass flow rates as specified previously. The optimum result for charging bed inlet air temperature at $50^{\circ} \mathrm{C}$ when mass flow rate is $0.0125 \mathrm{~kg} / \mathrm{sis} 55$ minutes as shown in Fig.2.3.

\section{Volume 5 Issue 2, February 2016 www.ijsr.net}




\section{International Journal of Science and Research (IJSR)}

ISSN (Online): 2319-7064

Index Copernicus Value (2013): 6.14 | Impact Factor (2014): 5.611

\subsection{Results for Air Inlet Temperature of $40^{\circ} \mathrm{c}$ During Discharging}

Releasing cycle of the bed was considered for distinctive mass flow rates when the charging was done at temperature $50^{\circ} \mathrm{C}$. Results demonstrate the temperature profile of bed for the mass stream rate of $0.00796 \mathrm{~kg} / \mathrm{s}$ and $50^{\circ} \mathrm{C}$ air inlet temperature. During discharging period the air at ambient temperature of $27.5^{\circ} \mathrm{C}$ was flowing through the bed with a mass flow rate of $0.00796 \mathrm{~kg} / \mathrm{s}, 0.00985 \mathrm{~kg} / \mathrm{s}$, and 0.0125 $\mathrm{kg} / \mathrm{s}$ respectively and $50^{\circ} \mathrm{C}$ air inlet temperature. The bed gets discharged completely when the temperature of the charged air after taking away the heat from the bed goes below that temperature i.e. $27.4^{\circ} \mathrm{C}$. The bed get discharged after 70 minutes with mass flow rate of $0.00796 \mathrm{~kg} / \mathrm{s}$ and air inlet temperature of $50^{\circ} \mathrm{C}$ while the ambient air temperature was $27.5^{\circ} \mathrm{C}$.

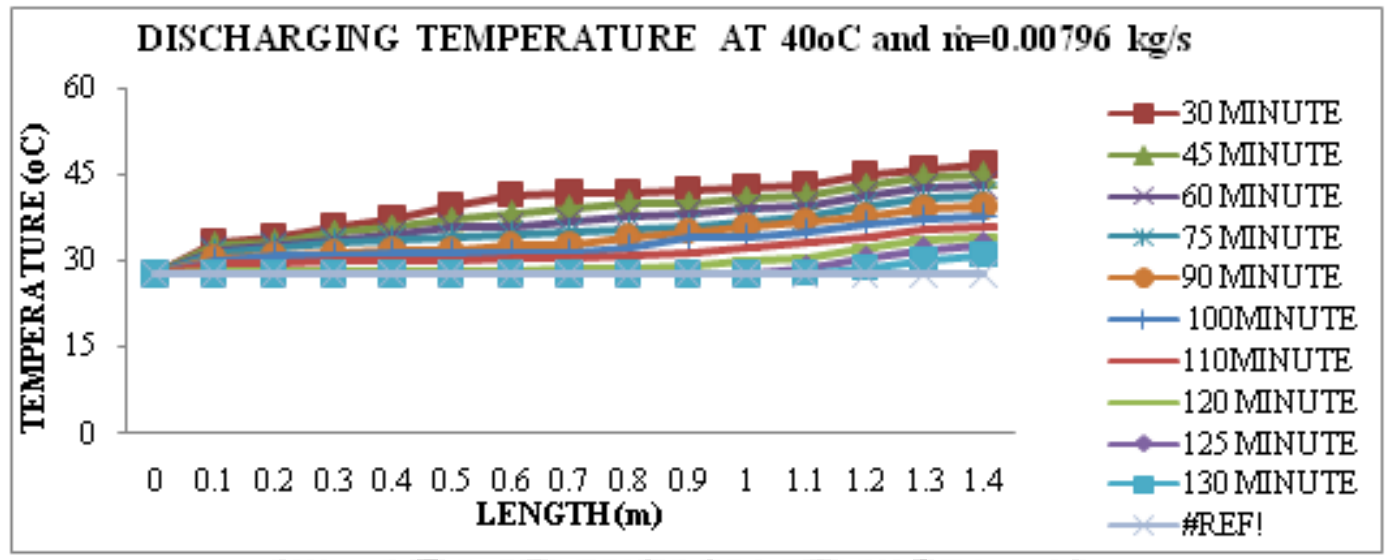

Figure 2.4: Temperature profile of discharging bed with $\dot{\mathrm{m}}=0.00796 \mathrm{~kg} / \mathrm{s}$ and ambient temperature of air as $33.4^{\circ} \mathrm{C}$

The discharging time of the bed decreases with increase in mass flow rate of air. The bed get completely discharged in 125 minutes with a mass flow rate of $0.00796 \mathrm{~kg} / \mathrm{s}$. Fig. 2.4, and Fig. 2.2, as compared to Fig. 2.3, shows decrease in discharging time with 110 minutes and 80 minutes for mass flow rate of $0.00985 \mathrm{~kg} / \mathrm{s}$ and $0.0125 \mathrm{~kg} / \mathrm{s}$ respectively for same inlet air temperature of $50^{\circ} \mathrm{C}$. The optimum result for discharging bed for maintained temperature at $50^{\circ} \mathrm{C}$ when mass flow rate is $0.00796 \mathrm{~kg} / \mathrm{s}$ is 130 minutes as shown in Fig 2.4.

\section{Conclusions}

The following are the optimum conclusion that we obtained from our experimental setup are as follows:

- Mass flow rate increases the charging time and discharging time decreases in the packed bed.

- During charging Nusselt number decreasing and at the time of discharging the value is increasing in the packed bed.

- As the mass flow rate increasing the pressure drop is decreasing in the packed bed.

- During charging value of Reynolds number decreasing and at the time of discharging the value is increasing in the packed bed.

- Optimum mass flow rate till now for charging is $\dot{\mathrm{m}}=0.0125 \mathrm{~kg} / \mathrm{s}$.

- Optimum mass flow rate till now for discharging is $\dot{\mathrm{m}}=0.00796 \mathrm{~kg} / \mathrm{s}$.

\section{References}

[1] Littman, H., and E. D. Sliva. 1970. Vol. 7. 4th Int. Heat Transfer Conference, Paris, Versailles.

[2] Hughes. P. J., S. A. Klein, and D. J. Close. 1976. Packed bed thermal storage models for solar air heating and cooling systems. Transactions of the ASME, Journal of Heat Transfer 98, No. 2:336-338.

[3] Riaz, M. 1977. Transient analysis of packed bed thermal storage systems. Solar Energy Journal 21:123-128.

[4] Bejan A. 1978. Two thermodynamic optima in the design of sensible heat units for units of energy storage.Journal of heat transfer.Vol. 100, November.

[5] Balakrishnan, 1979. Heat transfer in packed bed systems - A critical review. IndEngChem (Process Des Dev). 18(1): 30-40.

[6] Garg. H.P., Bandyopadhyay, B. and Sharma, V.K., 1981, Investigation of rock bed solar collector cum storage system, Energy Con. \& Mgmt. Vol. 21, pp. 275 - 282,

[7] Saez, A.E. and McCoy, B.J. 1982. Dynamic response of a packed bed thermal storage system-A model for solar air heating. Solar Energy J. 29: 201-6.79-80

[8] Shitzer, A. and Levy, M. 1983. Transient behavior of a rock bed thermal storage system subjected to variable inlet air temperature: analysis and design. Solar Energy Eng (ASME Trans). 105: 200-6.

[9] Adnan M. Waked, 1985, Solar energy storage in rocks, Solar \& Wind Technology, Vol. 3, No. 1, pp. 27-31.

[10] Mahmoud, S.A. 1992. Experimental study of a solar space heating model using Jordanian rocks for storage. Energy Convers. Mgmt. 33(9): 833-842.

[11] Choudhary, C. Chauhan, P.M. and Garg, H.P. 1995. Economic design of a rock bed storage device for storing solar thermal energy.Solar Energy. 55(1): 29-37. 